\title{
Editorial
}

\section{Recuperar el pasado, imaginar el futuro}

Hace poco volvíamos a escuchar el ya usual clamor generalizado. Es necesario que enfrentemos los problemas acuciantes de la realidad salvadoreña - violencia delincuencial, alto costo de la vida, carencia de oportunidades laborales-, desde una toma de postura ética clara, recuperando los valores ausentes y construyendo a nuestro alrededor los mecanismos institucionales idóneos. Se habla de "educar en valores", fortalecer la confianza en las instituciones, aplicar las leyes sin chistar, etc. No obstante, es evidente que no podemos partir de cero, ni como individuos ni como colectivo. Las propuestas sólidas no se construyen sobre la ignorancia de la propia historia, de la que se nos pinta y de la que se oculta. Y el ejercicio académico debe tener aún más claro esto.

Por otra parte, hay hechos que se ven mejor si observamos las imágenes que se crean para interpretarlos y expresarlos. Eventualmente, sucede que nos acercamos más a la sociedad si nos detenemos a esculcar en las figuras narrativas que se hacen de la misma o en las imágenes que refieren a sus procesos y tendencias. Esto es asi, por ejemplo, con las historias de los dioses, con los "origenes miticos" o con la dogmática religiosa. Así, incursionar en las figuras de la "segura mano de Dios" y la apelación absoluta a "su Ley"

\section{7}

Editorial 
puede que nos ayude a entender mejor la lógica que subyace a iniciativas sociales como la súper mano dura o la ley antiterrorista. Sobre todo cuando los que detentan el poder son tan aficionados a las metáforas teológicas y los discursos de salvación, es preciso que la crítica del cielo sea comprendida como crítica de la tierra.

Las imágenes teológicas sufren de distorsiones y manipulaciones. Lo que expresan no obtiene siempre una idéntica interpretación por parte de unos y otros, como sucede con las nociones del Reino de Dios, Jesucristo o el concepto de liberación entre los cristianos de la base, la jerarquía eclesiástica o los teólogos. Un estudio pormenorizado de la evolución de las ideas teológicas - como sucede con las nociones acerca de los "dogmas" o de qué es aquello que constituye el seguimiento de Cristo - nos acerca a la historia viviente de las mismas y no a la exhumación de creencias embalsamadas. Por eso es que los ejercicios reflexivos e historizadores de esos discursos son siempre necesarios para distinguir mejor entre los diversos intereses y compromisos concretos, de modo que podamos alumbrar ideas fructiferas y no meros recuerdos o repeticiones.

Ya que somos ineludibles constructores de imágenes, es necesario que nos las tomemos en serio. Pero, aún más, las imágenes - teológicas, literarias, históricas - proporcionan esa sutil tensión entre la critica de lo existente y la propuesta de lo nuevo — eso que podemos llamar "lo aún no alcanzado"-, y nos lo hacen ver desde dentro de los mismos discursos que utilizamos y valoramos consciente y cotidianamente. La toma de distancia critica debe orientarse incluso hacia lo que nos es más querido. Esto incluye las creencias profundamente arraigadas, las cuales son proclives a convertirse en "mistificaciones", creencias falsas que se nos presentan como "terribles simplificaciones" de la realidad e instrumentos para la manipulación interesada. Muchas veces, estas mistificaciones son inconscientes, pero siempre deberian ser combatidas. La investigación histórica que no teme volver sobre los "casos cerrados" - como sucede con el tema de la Guerra Fría- no es sólo un recurso que busca vivificar nuestra relación con los hechos pasados, sino, más aún, pretende que miremos dentro de nuestros temores y esperanzas más intimos.

Muchos de estos temores nacen de verdaderos horrores, que son objetivos e inexcusables. Pero es más grave que ciertas voces los hayan convertido 
también en fuente de justificación para la construcción de politicas sociales excluyentes. Asi sucede con la compulsiva insistencia en el problema del terrorismo y la pléyade de cruzadas orquestadas para combatirlo, al mismo tiempo que se elude el abordaje de un mayor número de problemas, los cuales afligen a más personas en el mundo entero. Hay mucho de inconsciencia, o incluso actitud de connivencia con el crimen, en quienes abogan por compromisos con los llamados "objetivos del milenio", mientras apoyan o simplemente evaden pronunciarse sobre las politicas de guerra y destrucción de la vida de miles. Si vamos más lejos, es posible suponer que existe un vínculo perverso entre el apoyo a la infame politica estadounidense en Irak y la negativa a investigar las masacres ocurridas dentro de nuestro pais. Pero también resulta plausible que los que conscientemente defienden los derechos humanos y los "valores de Occidente" se inclinen hacia una lectura paranoica de las figuras en las que se expresan los otros, los extraños (aliens), tal vez disfrazándola de preocupación por el resurgimiento de la fuerza politica de las religiones y los fundamentalismos. A ellos deberiamos recordarles que se necesita mucha más valentía para descubrir al fundamentalista que llevamos dentro.

Parece más sencillo construir muros. Pero más sencillo no significa, necesariamente, que sea más justo o más eficaz siquiera. Los muros llevarán siempre aparejados los medios para saltárselos. Pasó en Berlin, sucede en Palestina y será asi en el desierto mexicano. Ahora, las voces se han elevado, desde todos los flancos ideológicos, para condenar semejante contradicción en un mundo atiborrado de palabras como "globalización", "apertura" y "libre comercio". Es curioso que justo después de que descubríamos que el mundo es un globo —la bomba en Hiroshima y Nagasaki se cernía como una sombra de muerte sobre todos-, aparecieran los muros emblemáticos. Algunos muy visibles, como en Berlín y Corea. Pero también están los invisibles: la delirante paranoia que trasluce en expresiones como la del "choque de civilizaciones" o la "amenaza a los valores de occidente". ¿Será que, como sostiene Franz Hinkelammert, algunos seguimos pensando que no vivimos sobre un globo sino sobre una "planicie infinita"? ¿Hasta cuándo seguiremos creyendo que podemos estirar cada vez más el "territorio", echando fuera a los que nos resultan incómodos? Necesitamos modificar nuestra ética interpretando la geometría no euclidiana de nuestra realidad: no hay propiamente "ex- 
cluidos", pues ya no hay más un "nuevo mundo" al que puedan ir a parar. En todo caso, el nuevo mundo sólo podrá ser éste o no será.

Una lección sobre los juegos de espejos y la construcción de imágenes es que, mientras más se parezcan a la realidad, más posible será que nos induzcan a error. Siempre es bueno mantener la cabeza fría y no creer que la narración es el hecho, ni que las imaginaciones son las personas (o las instituciones). Y no hay que dar demasiada importancia a esas distinciones escolásticas entre "memoria" e "bistoria", señalando la inmediatez de una y la lejanía de la otra. El desmemoriado al que debemos combatir no es el que no recuerda todo, sino el que no recuerda aquello que los vivientes a su lado le exigen recordar. A este irresponsable no le preocupa tener "lagunas" en lo que se refiere a la verdad sobre la vida que le rodea. Y para estos efectos es indiferente si se trata de una verdad cercana o lejana en el tiempo. Después de todo, el tiempo de las víctimas no es el mismo que el de los victimarios o el de los indiferentes. La recuperación de la memoria histórica es fundamental porque hay una exigencia presente de verdad esclarecida. Necesitamos construir lugares para el encuentro fraterno y esperanzador, pero esto sólo lo lograremos poniendo delante los hechos que han querido ocultarse o que han sido distorsionados.

Mas no veamos esta recuperación como mera disección del pasado o como una renuncia a pensar el futuro de modos nuevos, como si estuviéramos condenados a repetirnos. Al contrario, la mirada a nuestra historia nos posibilita unos modos novedosos de hablar, de pensar y soñar. Si bien la adoración del idolo puede ser la renuncia a pensar la vida de manera renovada — como pasa con la adoración de los caudillos, de las estructuras anquilosadas o de las viejas maneras de ser un "maestro", un "lider" o un "creyente"-, la mirada a la historia y el recurso a la memoria puede hacerse desde un compromiso con la realización de la vida ahora, un ahora que no se fija de una vez para siempre, sino que es cambio y transformación creadora. No se trata de quedarse en los meros hechos, sino de imaginar formas de "hacer nuevas todas las cosas". Pero, para ello, debemos querer pensar de otra manera. 